\title{
PERAN MEDIA GAMBAR \\ DALAM MENINGKATKAN MINAT BELAJAR SISWA KELAS V DI SD N 1 TIYINGGADING
}

\author{
I Wayan Martha \\ Fakultas Ilmu Agama dan Kebudayaan \\ Universitas Hindu Indonesia \\ e-mail: marthabadung@gmail.com \\ Ni Kadek Ayu Feby Puspitarini \\ Fakultas Ilmu Agama dan Kebudayaan \\ Universitas Hindu Indonesia \\ Denpasar
}

\begin{abstract}
This article discusses the use of Hindu image media in improving students' interest in learning. As described, what are the creativity of Hindu religious education teachers in improving students'learning interests, what efforts are done by Hindu Guru in the utilization of Hindu image media. This research was conducted in SD N 1 Tiyinggading. Based on the research that can be explanation that the development of image media in Indonesia at this time very rapidly over time, as well as the application of the teachings of Hinduism that today should be the first step in using the media as a means of media support Hindu learning process. By utilizing the media images in the process of studying Hinduism, it will be a creative and fun learning process so as to increase student learning interest in SD N 1 Tiyinggading.
\end{abstract}

Keywords: Hindu Image Media, Increasing Interest in Learning

\begin{abstract}
Abstrak
Artikel ini membahas tentang pemanfaatan media gambar agama Hindu dalam meningkatkan minat belajar siswa. Adapun yang dideskripsikan adalah apa saja kreativitas guru pendidikan agama Hindu dalam mengingkatkan minat belajar siswa, upaya-upaya apa saja yang dilakukan Guru Agama Hindu dalam pemanfaatan media gambar Hindu. Penelitian ini dilakukan di di SD N 1 Tiyinggading. Berdasarkan penelitian yang dilakukan dapat penjelasan yakni perkembangan media gambar di Indonesia pada saat ini sangat pesat seriring berjalannya waktu, demikian pula dengan penerapan ajaran agama Hindu yang saat ini harus menjadi langkah awal dalam menggunakan media gambar sebagai sarana yang medukung proses belajar agama Hindu. Dengan memanfaatkan media gambar dalam proses
\end{abstract}


belajar agama Hindu, maka akan menjadi proses belajar yang kreatif dan menyenangkan sehingga dapat meningkatkan minat belajar siswa di SD N 1 Tiyinggading.

Kata Kunci : Media Gambar Hindu, Meningkatkan Minat Belajar

\subsection{Pendahuluan}

Perkembangan dunia pendidikan pada saat ini sangatlah penting untuk menciptakan manusia yang berkualitas dan dapat bersaing pada era globalisasi saat ini. Pendidikan menjadi bagian terpenting untuk pengembangan sumber daya manusia. Setiap individu yang ada, sudah membawa potensinya masing-masing saat dilahirkan. Setiap potensi yang ada perlu dikembangkan untuk menjalani kehidupan di dunia ini. Untuk mengembangkan potensi yang ada, diperlukan suatu proses pendidikan. Pendidikan berkualitas menjadi bagian terpenting dalam mengembangkan sumber daya manusia.

Dalam perkembang pendidikan yang cerdas dan berkualitas, perlu adanya kreatifitas dalam bentuk pendidikan, sehingga dapat meningkatkan mutu pendidikan dan membuat siswa lebih mudah dalam memahami pelajaran yang akan di pelajari. Manusia yang dapat memanfaatkan pendidikan dengan budi perkerti yang baik dan luhur, akan menjadi manusia yang bermartabat dengan nilai-nilai hidup yang baik yang harus dipertahankan, karena pada hakekat manusia mempunyai hasrat untuk dapat hidup dengan layak.

Prilaku yang terjadi saat proses belajar yang tidak dimengerti oleh siswa akan menimbulkan penurunan minat belajar, yang mengakibatkan siswa menjadi tidak menanggapi dengan serius proses pembelajaran yang dilakukan. Oleh karena itu perlu adanya sebuah terobosan yang dapat mengembalikan minat belajar siswa dan membuat proses belajar lebih mudah di mengerti.
Sehubungan dengan hal di atas, guru Pendidikan Agama Hindu mempunyai peranan yang sangat penting dalam membina tingkah laku anak didik dan membuat para anak didik dapat memahami dengan mudah materi yang akan di pelajari. Guru merupakan unsur manusiawi yang dekat hubungannya dengan anak didik atau siswa dalam melakukan pendidikan sehari-hari disekolah dan banyak yang menentukan keberhasilan siswa dalam mencapai pendidikan yang berkualitas.

Dari uraian di atas dapat katakan bahwa pentingnya kreativitas Guru Agama Hindu dalam memanfaatkan media yang ada, sebagai alat bantu guru untuk mengajarkan materi agama hindu yang membuat anak didik lebih mudah dan cepat mengerti tentang materi yang diajarkan oleh guru. Sebagai contoh di lingkungan sekolah kelas V di SD Negeri 1 Tiyinggading antara lain sering mengantuk saat proses belajar berlangsung, tidak tau materi saat di tanya tentang materi yang di ajarkan, mengobrol dengan teman duduk saat proses belajar di lakukan.

Salah satu faktor yang mempengaruhinya yaitu perlunya kreatifitas dalam proses belajar, contohnya dengan memanfaatkan media gambar sehingga anak didik lebih berminat dalam mengikuti pelajaran. Maka disini penulis mengangkat judul "Pemanfaatan Media Gambar Hindu Dalam Meningkatkan Minat Belajar Siswa Kelas V di SD N 1 Tiyinggading, Kecamatan Selemadeg Barat, Kabupaten Tabanan”.

\subsection{Metode Penelitian}

Observasi merupakan salah satu teknik 
pengumpulan data yang tidak hanya mengukur sikap dari responden (wawancara dan angket) namun juga dapat digunakan untuk merekam berbagai fenomena yang terjadi (situasi, kondisi). Metode observasi adalah cara untuk mendapatkan data dengan jalan pengamatan secara langsung dengan mencatat kejadian atau peristiwa yang ada di lapangan, dengan mengamati langsung kelapangan di harapkan dapat memperoleh data yang akurat mengenai Pemanfaatan Media Gambar Hindu di Sekolah Dasar Negeri 1 Tiyinggading. Menurut Kartono (1980: 142), pengertian observasi adalah: "studi yang disengaja dan sistematis tentang fenomena sosial dan gejala-gejala psikis dengan jalan pengamatan dan pencatatan". Kemudian, Banister dkk, 1994 dalam Poerwandari (1998: 62), menyebutkan bahwa 'Semua bentuk penelitian psikologis, baik itu kualitatif maupun kuantitatif mengandung aspek observasi di dalamnya. Istilah observasi diturunkan dari bahasa Latin yang berarti "melihat" dan "memperhatikan", Sedangkan Prof.Heru (2008: 34) Observasi merupakan pengamatan yang sebuah studi kasus atau pembeljaran yang dilakukan dengan sengaja, terarah, urut, dan sesuai pada tujuan. Pencatatan pada kegiatan pengamatan disebut dengan hasil observasi. Hasil observasi tersebut dijelaskan dengan rinci, tepat, akurat, teliti, objektif, dan bermanfaat.

Wawancara adalah suatu cara untuk mengumpulkan data dengan mengajukan sejumlah pertanyaan-pertanyaan langsung oleh wawancara kepada responden, dengan tujuan untuj mengetahui pendapat, persepsi, perkembangan dan pengamatan. Dan jawaban-jawaban responden tersebut dicatat dan direkam (Iqbal, 2002:85). Dalam hal ini peneliti akan mewawancarai Kepala Sekolah, Guru Bidang Studi Agama Hindu, Wali Kelas, Staf dan Siswa. Wawancara atau interview adalah suatu cara untuk memperoleh data dengan cara tanya jawab yang sistematis, disertai dengan pencatatan. Wawancara ini juga merupakan metode menyelidiki dengan mempergunakan pertanyaan-pertanyaan (Koentjaaraningrat, 1981:162). Berdasarkan funsinya metode wawancara digunakan sebagai metode primer yaitu alat pengumpulan data yang berkedudukan utama dan kedua sebagai metode pelengkap yaitu untuk menguji kebenaran dan kemantapan data yang terkumpul dengan cara lain sebagai alat pertimbangan dalam memutuskan suatu masalah.

Dalam penelitian ini digunakan interview berstruktur yaitu dimana peneliti melakukan wawancara dengan penuh keakraban bersifat terbuka tetapi pembicaraan tidak melebar karena penelitian ini menggunakan pedoman wawancara. Selain itu menggunakan wawancara tidak berstruktur yaitu wawancara ini dilakukan dengan menggunakan media atau alat perantara seperti handphone dan alat perekam.

\subsection{Pembahasan}

\subsubsection{Kreatifitas Guru Agama Hindu dalam Meningkatkan Minat Belajar}

Melihat perkembangan siswa Sekolah Dasar Negeri No 1 Tiyinggading tidak lepas dari latar belakang anak tersebut mulai dari segi karakternya, kebiasaan-kebiasaan malas, manja dirumah yang sering juga dibawa disekolah. Dengan adanya standar pembelajaran atau kurikulum dapat disesuaikan dengan mendidik siswa.

Orang tua merupakan pendidikan yang utama dan pertama dalam membentuk kepribadian anak. Penampilan orang tua merupakan unsur-unsur pendidikan secara tidak langsung yang dengan sendirinya akan diteladani oleh anaknya. Maka sebaliknya orang tua harus memperlakukan anaknya dengan penuh kasih sayang dan penuh 
perhatian sehingga akan memudahkan untuk moral anak.

Peran orang tua dalam membimbing dan mendidik anak dapat diperlukan adana pembiasaan dan latihan pembelajaran agama Hindu dalam kehidupan sehari-hari, maka mudah membentuk sikap yang baik terhadap anak . peran orang tua sangat menentukan di dalam memberikan pendidikan agama dalam keluarganya, karena orang tua tidak hanya membekali anaknya dengan materi saja tapi harus diimbangi dengan unsur spiritual. Anak yang dibesarkan dengan pendidikan agama yang baik, maka segala tingkah lakunya akan selalu mencerminkan nilai-nilai ajaran agama.

Setiap sekolah sebagai sarana pengelola pendidikan, meletakan tujuannya agar anak didiknya menjadi orang yang baik, dan menerapkan nilai-nilai agama sehingga berguna bagi bangsa dan Negara. Namun untuk menggapai tujuan tersebut tidaklah mudah. Adanya upaya-upaya yang mengarahkan pada pencapaian tujuan yaitu meningkatkan minat belajar siswa, di Sekolah Dasar Negeri No 1 Tiyinggading, telah berupaya semaksimal mungkin agar tujuan yang diinginkan dapat tercapai dengan baik. Berdasarkan wawancara dengan guru agama Hindu di Sekolah Dasar Negeri No 1 Tiyinggading, adapun upayaupaya yang dilakukan dalam meningkatkan minat belajar siswa antara lain:

\subsubsection{Menyediakan Media Gambar Hindu}

Dalam kamus bahasa indonesia media gambar artinya adalah suatu gambar yang berkaitan dengan materi pelajaran yang berfungsi untuk menyampaikan pesan dari guru kepada siswa. Media gambar ini dapat membantu siswa untuk mengungkapkan informasi yang terkandung dalam masalah sehingga hubungan antar komponen dalam masalah tersebut dapat terlihat dengan lebih jelas. Jadi dapat disimpulkan media gambar Hindu adalah gambar yang berisikan materi pelajaran tentang nilai-nilai agama Hindu.

Dari penelitian yang dilakukan peneliti menggunakan materi tentang Catur Guru dalam mengimplementasikan media gambar kedalam bentuk materi pelajaran seperti di bawah ini:

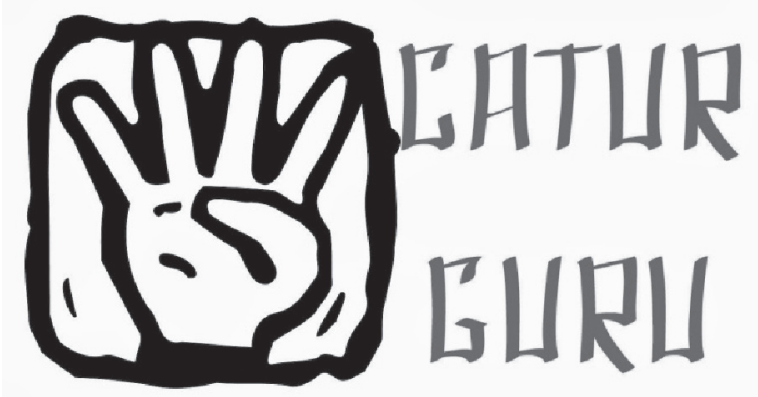

Catur Guru terdiri dari dua kata yaitu Catur artinya empat dan Guru artinya guru. Catur Guru adalah empat guru yang harus kita hormati sebagaimana dijelaskan dalam ajaran hindu, catur guru terdiri dari empat (4) guru yaitu

\section{Guru Rupaka}

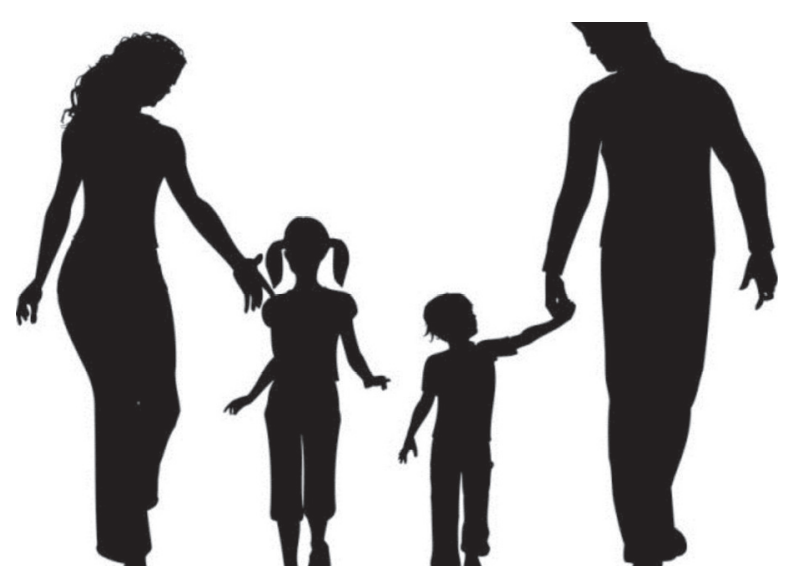

Hubungan baik antara orang tua dengan anak wajib dilakukan, karena orang tua sangat menentukan baik buruknya masa depan anak. Anak perlu diperhatikan secara detail semua kegiatannya baik di rumah, di sekolah, dan di masyarakat. Apabila sejak kecil mendapat perhatian, ke depan anak akan tumbuh menjadi generasi 
yang baik. Jangan mengandalkan anak belajar di sekolah saja, karena waktu belajar di sekolah sangat terbatas. Orang tua berkewajiban mendampingi anaknya ketika belajar di rumah.

\section{Guru Pengajian}

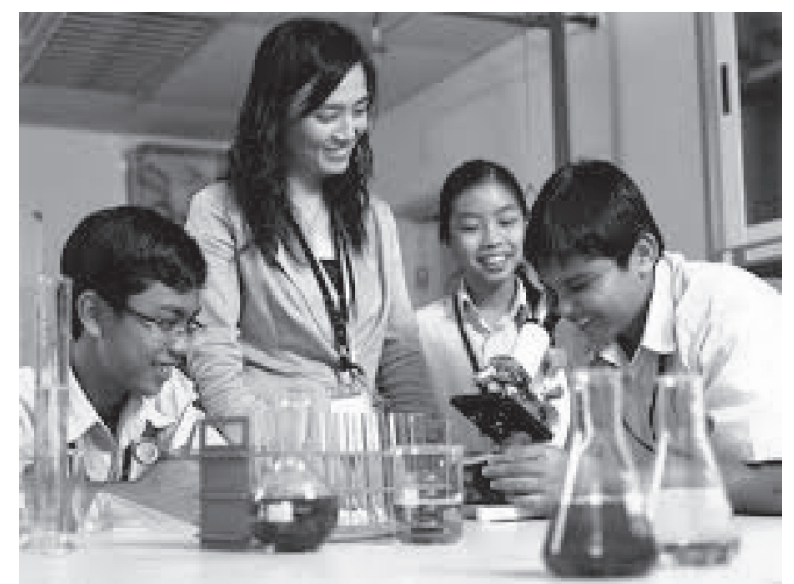

Hubungan antara siswa dengan guru wajib dilakukan dengan harmonis. Mengapa demikian? Siswa membutuhkan pengetahuan dari guru dan sebaliknya guru wajib mentransfer ilmunya kepada para siswa. Hal itu bisa diwujudkan apabila siswa dan guru sama-sama memiliki disiplin yang baik.

\section{Guru Wisesa}

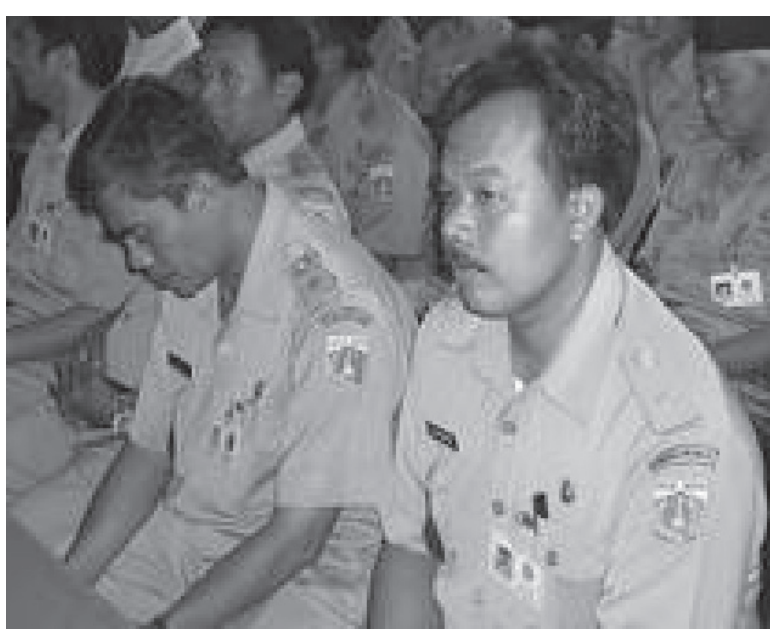

Agar terjalin hubungan yang harmonis di masyarakat, harus dimulai dari masing- masing keluarga. Keharmonisan itu dapat kita lihat dalam kehidupan sosial masyarakat.

\section{Guru Swadiyaya}

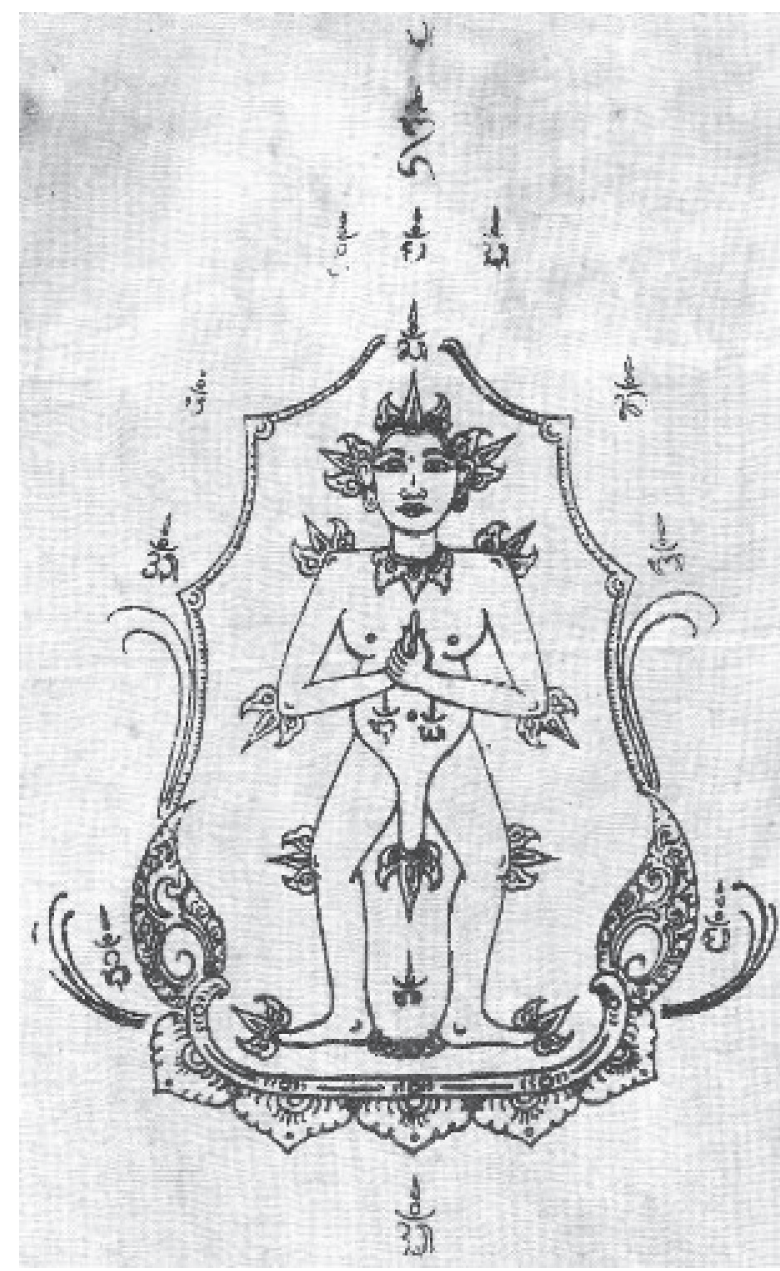

Guru Swadyaya disebut pula guru sejati. Dinamakan guru sejati karena Beliau adalah Ida Sang Hyang Widhi Wasa. Beliaulah yang telah menciptakan alam semesta dengan segenap isinya ini, kemudian memelihara dan melindunginya dan akhirnya juga melebur atau mengembalikan ke dalam bentuk asalnya. Dinyatakan sebagai guru karena Tuhan adalah pembimbing utama bagi umat manusia yang tidak ada bandingannya. Beliau Mahatau, beliau juga Mahakuasa, dan Mahasakti. Karena itu sebagai manusia kita perlu mewujudkan rasa bhakti kita kepada Tuhan 
dengan sungguh-sungguh dan tulus ihklas.

Demikian penerapan dari media gambarHinduyang dapatdiimplementasikan terhadap materi agama hindu. Dalam pemanfaatan media gambar Hindu, guru di wajibkan berkreatifitas dalam penyajian gambar hindu sehingga siswa dapat membuat siswa lebih paham akan materi agama hindu dalam belajar, sehingga akan tumbuh minat belajar dari para siswa .

Berdasarkan hasil wawancara dengan kepala sekolah dapat di peroleh keterangan bahwa dalam rangka memanfaatkan media gambar Hindu di Sekolah Dasar Negeri 1 Tiyinggading ini berjalan dengan cukup baik. Minat belajar yang ditunjukan oleh siswa dapat diamati dari tata cara siswa mempelajari materi agama Hindu dengan memanfaatkan media gambar Hindu. Dengan memanfaatkan media gambar sebagai sarana belajar materi agama Hindu, minat dan semangat siswa saat belajar menjadi meningkat, sehingga pemahaman siswa terhadap materi agama Hindu dapat lebih mudah dimengerti oleh siswa.

\subsubsection{Kendala Belajar Menggunakan Media Gambar Hindu}

Melalui bimbingan yang dilakukan guru agama Hindu di Sekolah Dasar Negeri 1 Tiyinggading, kendala dalam belajar menggunakan media gambar yaitu proses penyiapan materi yang di lakukan oleh guru menjadi lebih lama, kreatifitas seorang guru yang menentukan bagus tidaknya media gambar yang akan di gunakan yang dapat mempengaruhi pemahaman siswa terhadap materi pelajaran, diperlukannya alat bantu dalam menampilkan media gambar yang akan di pergunakan. Alat bantu ini berupa leptop, LCD proyektor. Contoh kendala lain yang dihadapi yaitu:

1) Guru belum terbiasa menggunakan media gambar hindu dalam pembelajaran. Hal itu dapat dilihat dari cara guru pada saat pertemuan awal tindakan yang masih kaku, canggung dan belum terbiasa dalam menggunakan media gambar Hindu secara optimal,

2) Ketika gambar kurang sesuai dengan materi. Hal tersebut terlihat pada saat guru menyampaikan materi dengan menggunakan media gambar, guru terlihat bingung dan membutuhkan penjelasan yang lebih untuk memperbaiki penampilan gambar.

3) Pada saat menampilkan gambar yang kurang menarik yang kadang kala mengganggu proses belajar. Hal ini disebabkan oleh ketertarikan/antusias siswa terhadap gambar Hindu yang disajikan.

4) Mengenai teknis pembuatan media gambar Hindu yang membutuhkan keahlian/keterampilan khusus. Selain itu dibutuhkan pula modal yang tidak sedikit.

Demikian kendala yang dihadapi saat menggunakan media gambar Hindu sebagai sarana belajar, dengan demikian setiap guru wajib menguasai media gambar yang akan digunakan, sehingga proses belajar dapat dilakukan dengan baik dan mampu meningkatkan minat belajar siswa kelas $\mathrm{V}$ di SD N 1 Tiyingading.

\subsubsection{Manfaat yang Ditimbulkan}

Dengan adanya penerapan metode belajar menggunakan media gambar Hindu, beberapa batasan saat mempelajari materi agama Hindu dapat diatasi dengan mudah. Adapun manfaat penggunaan gambar Hindu sebagai media pendidikan antara lain sebagai berikut:

1) Media gambar Hindu dapat menjelaskan pengertian-pengertian yang tidak dapat dijelaskan dengan kata-kata. "one picture is worth 
athousand words" atau satu gambar sama nilainya dengan seribu kata. Dengan alat bantu gambar siswa akan lebih mudah dalam memahami pelajaran yaitudenganmemperlihatkan gambar-gambar dari pada kata-kata atau pengertian verbal.

2) Gambar dapat membangkitkan minat untuk sesuatu yang baru yang akan dipelajari. Dengan menggunakan media gambar Hindu, horison pengalaman anak semakin luas, persepsi semakin tajam, dan konsepkonsep dengan sendirinya semakin lengkap, sehingga keinginan dan minat baru untuk belajar selalu timbul.

3) Gambar dapat memperbaiki pengertian-pengertian yang salah, Media gambar Hindu dapat menyampaikan pengertian-pengertian atau informasi dengan cara yang lebih konkret atau lebih nyata dari pada yang dapat disampaikan oleh katakata yang di ucapkan, di cetak atau di tulis. Karena itulah gambar membuat sesuatu pengertian atau informasi menjadi lebih berarti. Kesanggupan berfikir abstrak hanya diperoleh dengan latihan dan dibangun diatas pengalaman-pengalaman terdahulu dengan realita yang nyata. Dengan melihat sekaligus mendengar, orang yang menerima pelajaran, penerangan dan penyuluhan, keragu-raguan atau salah pengertian dapat dihindarkan secara efektif.

4) Gambar dapat mengatasi batas ruang dan waktu. Melalui gambar dapat diperlihatkan kepada siswa gambargambar benda yang jauh atau yang terjadi beberapa waktu lalu.

5) Gambar dapat mengatasi kekurangan daya mampu panca indera manusia Misalnya: benda-benda kecil yang tidak dapat di lihat dengan mata dapat di perbesar sehingga dapat di lihat dengan jelas.

Dengan demikian saat belajar materi agama Hindu sebelumnya hanya terdapat materi berupa tulisan yang banyak, sehingga pemahaman terhadap materi masih mengalami kendala, tapi saat memanfaatkan media gambar Hindu sebagai alat dalam pelajaran, maka siswa dapat memahami dan membayangkan maksud dari setiap materi agama Hindu yang ada, karena gambar yang dijadikan media dalam pelajaran dapat membuat siswa memahami langkah-langkah yang diperlkukan dalam mempelajari materi agama Hindu.

\subsubsection{Manfaat dalam Meningkatkan Minat Belajar}

Manfaat yang dirasakan dalam meningkatkan minat belajar siswa, supaya anak-anak dibantu pemahamannya sehingga lebih mengerti dan lebih besar daya ingatnya. Supaya anak-anak dapat melihat hubungan antara ilmu yang dipelajarinya dengan alam sekitar dan masyarakat. Minat belajar dapat menumbuhkan kegairahan belajar. Dapat meningkatkan aktivitas dan kreatifitas. Efisiensi waktu dan efisiensi motivasi dalam proses belajar mengajar. Manfaat dalam proses pembelajaran bukan merupakan fungsi tambahan tetapi mempunyai fungsi tersendiri, sebagai manfaat untuk mewujudkan situasi pembelajaran yang efektif.

Pengaruh minat belajar merupakan bagian yang integral dari keseluruhan situasi mengajar. Ini berarti bahwa minat belajar merupakan salah satu unsur yang harus dikembangkan guru pendidikan agama Hindu. Meningkatkan minat belajar dalam pengajaran lebih diutamakan untuk mempertinggi mutu pembelajaran. Dengan perkataan lain dengan meningkatkan minat belajar, hasil belajar yang dicapai akan tahan lama diingat siswa, sehingga pembelajaran 
mempunyai nilai tinggi. Dengan demikian meningkatkan minat belajar dalam proses pembelajaran akan lebih kondusif, efektif dan efisien. Siswa akan termotivasi untuk belajar, karena mereka tertarik dan lebih menikmati proese belajar atas pelajaran yang diterimanya.

Di samping itu orang tua mempunyai manfaat dalam mendidik dan meningkatkan kemampuan anak dalam belajar, guru khusunya guru agama Hindu juga mempunyai peranan dalam meningkatkan minat belajar siswa. Peran guru akan senantiasa menggambarkan tingkah laku anak yang diharapkan dalam interaksi baik dengan siswa yang utama, sesama guru maupun dengan staf yang lainnnya. Ada beberapa peranan guru di dalam kegiatan belajar mengajar sebagai berikut :

1. Guru sebagai sumber belajar, yaitu guru harus menguasai materi pelajaran yang sedang di ajarkan.

2. Guru sebagai fasilitator, yaitu guru berperan dalam memberikan pelayanan untuk memudahkan siswa dalam kegiatan proses pembelajaran.

3. Guru sebagai demonstrator, adalah peran sebagai mempertunjukan kepada siswa segala sesuatu yang dapat membuat siswa lebih mengerti dan memahami setiap pesan yang disampaikan.

4. Guru sebagai pengelola yaitu guru berperan dalam menciptakan iklim belajar yang memungkinkan siswa dapat belajar dengan nyaman.

5. Guru sebagai pembimbing yaitu guru berperan membimbing siswa/ agar dapat memahami setiap pesan yang disampaikan.

6. Guru sebagai motivator, yaitu menumbuhkan motivasi belajar siswa.

7. Guru sebagai evaliator, yaitu guru berperan untuk mengumpulkan data atau informasi tentang keberhasilan pembelajaran yang telah dilakukan.

Sekolah bukan sekedar merupakan lapangan untuk mempertajam intelektual saja, melainkan peranan jauh lebih luas. Di dalamnya berlangsung beberapa bentukbentuk dasar dari pada kelangsungan pendidikan. Pada umumnya pembentukan sikap-sikap belajar bekerja sama dengan kelompok, melaksanakan tuntunan-tuntunan dan contoh yang baik, belajar mengendalikan diri demi kepentingan sendiri maupun orang lain. Memperoleh pengajaran menghadapi persaingan dan lain sebgainya, semua itu mempunyai fungsi untuk mencerdaskan otak anak-anak seperti yang dibuktikan dengan tes-tes intelegensi. Jadi disini sekolah berperan besar dalam mengembangkan sikap mental maupun sikap sosial anak,karena disamping sekolah merupakan tempat untuk mempertajam ilmu pengetahuan, di sekolah juga diajarkan pendidikan yang dapat membentuk tingkah laku anak kearah yang lebih baik dalam mengadakan interaksi dengan lingkungannya.

Kreativitas guru agama Hindu melalui pembelajaran yang berlangsung di sekolah, sangat berperan dalam meningkatkan etika siswa dan pemahaman terhadap nilai-nilai agama oleh karena itu selain orang tua, guru pendidikan agama Hindu juga sangat penting untuk membimbing siswa menjadi generasi penerus bangsa yang berbudi pekerti yang luhur serta mempunyai keyakinan (sradha) yang teguh dan tekun melaksanakan ajaran agama.

Dalam hasil wawancara dengan beberapa informan pada tanggal 2 November 2017 diperoleh beberapa kreativitas guru khususnya Guru Pendidikan Agama Hindu dalam meningkatkan minat belajar siswa kelas V Sekolah Dasar Negeri No 1 Tiyinggading adalah sebagai berikut: 


\subsubsection{Guru Pendidikan Agama Hindu Sebagai Pembentuk Kreativitas}

Setiap siswa memiliki potensi untuk melakukan aktifitas yang kreatif. Setiap siswa baru yang memasuki proses belajar, dalam benak mereka selalu diiringi dengan rasa ingin tahu. Pada tahap ini guru diharapkan untuk merangsang siswa untuk melakukan apa yang dinamakan dengan learning skills acquired, misalnya dengan jalan memberi kesempatan siswa untuk bertanya (questioning), menyelidik (inquiry), mencari (searching), menerapkan (manipulating) dan menguji coba (experimenting).

Kebanyakan yang terjadi di lapangan adalah aktifitas ini jarang ditemui karena siswa hanya mendapatkan informasi yang bagi mereka adalah hal yang abstrak. Rasa ingin tahu siswa harus dijaga dengan cara memberikan kesempatan bagi mereka untuk melihat dari dekat, memegangnya serta mengalaminya. kreatifitas dikembangkan dari proses pembelajaran yang tepat bukan dari materi-materi kurikulum, tapi bagaimana guru menciptakan proses pembelajaran di dalam kelas agar anak senang bertanya, suka meneliti, dan senang menciptakan.

Dari penjelasan diatas dapat diambil kesimpulan bahwa seorang guru diharapkan mampu memberikan kesempatan bagi siswa untuk mendemontsrasikan perilaku yang kreatif. Beberapa hal yang dapat dilakukan oleh guru untuk meningkatkan kreatifitas siswa antara lain :

1. Guru menghargai hasil-hasil pikiran kreatif siswa

2. Guru respek terhadap pertanyaan, ide dan solusi siswa yang tidak biasa

3. Guru menunjukkan bahwa gagasan siswa adalah memiliki nilai yang ditunjukkan dengan cara mendengarkan dan guru memberi kesempatan kepada siswa untuk menjelaskan kepada orang lain.

Sebagai guru agama Hindu di Sekolah Dasar Negeri 1 Tiyinggading wajib mengembangkan kreativitas setiap siswa untuk membuat suasana belajar semakin aktif dan menjadikan pelajaran agama Hindu semakin menyenangkan, itu bertujuan untuk semakin meningkatkan minat belajar siswa, karena jika setiap pelajaran menjadi menyenangkan, maka pelajaran yang dipelajari akan semakin mudah di mengerti.

\subsubsection{Guru Pendidikan Agama Hindu Sebagai Teladan}

Guru merupakan contoh awal yang dilihat anak didiknya maupun di lingkungan masyarakat. Guru sebagai teladan di sekolah di bantu peran teladan orang tua, karena itu guru dapat lebih mudah dalam mengajarkan hal-hal keagamaan kepada anak didiknya. Guru memberikan contoh mengenai pembelajaran dalam bertingkah laku atau beretika dalam kehidupan sehari-hari, sehingga siswa dapat mengendalikan dirinya dari tindakan atau perbuatan yang dapat merugikan diri sendiri maupun orang lain, seperti berbuat, berkata dan berpikir yang kurang baik, dan hendaknya selalu mengamalkan perbuatan baik sehingga terhindar dari masalah yang di timbulkan akibat berperilaku yang kurang baik.

Selain itu guru agama Hindu juga merupakan bagian dalam kompetensi guru yaitu dapat diuraikan sebagai berikut. Pengertian Kompetensi adalah seperangkat pengetahuan keterampilan dan perilaku tugas yang harus dimiliki seorang guru. Seteah dimiliki, tentu harus dihayati, dikuasai dan diwujudkan oleh guru dalam melaksanakan tugas keprofesionalan di dalam kelas yang disebut sebagai pengajaran. Jadi kompetensi guru merupakan kemampuan seorang guru dalam 
melaksanakan kewajiban-kewajiban secara bertanggung jawab dan layak. Dari beberapa gambaran pengertian tersebut, dapat disimpulkan bahwa kompetensi merupakan kemampuan dan kewenangan guru dalam melaksanakan profesi keguruannya." Seseorang yang kompeten di bidang tertentu adalah seseorang yang menguasai kecakapan kerja atau keahlian selaras dengan tuntutan bidang kerja yang bersangkutan dan dengan demikian ia mempunyai wewenang dalam pelayanan social di masyarakatnya. Secara nyata orang yang kompeten mampu bekerja di bidangnya secara efektif-efisien. Artinya, kadar kompetensi seseorang tidak hanya menunjuk kuantitas tetapi sekaligus menunjuk kualitas kerja. Ada 4 hal penting yang dapat diusahakan oleh guru untuk membangun kemantapan diri sekaligus mengembangkan kompetensi diri dan kompetensi mengajarnya, di antaranya:

1) membangun kemantapan diri.

2) mengikuti kegiatan-kegiatan ilmiah (seminar, lokakarya, diskusi ilmiah, dsb) secara berkesinambungan dalam merespons secara aktif setiap isu-isu terbaru yang berkembang dunia pendidikan.

3) mempelajari hasil-hasil penelitian dari berbagai literatur tentang kompetensi mengajarnya yang berhubungan dengan prestasi subjek didik. Sebagai hasil dari analisis tugas mengajar pada tingkat dan kurikulum yang berbeda.

Bagian-bagian dari kompetensi guru dapat dibagi menjadi 4 (empat) yaitu:

1) Kompetisi Pedagogik merupakan kemampuan guru dalam pengolahan pembelajaran untuk kepentingan peserta didik.

2) Kompetensi kepribadian mencakup kepribadian yang baik, stabil, dewasa, arif dan bijaksana. Tentu saja berakhlak mulia, serta menjadi teladan bagi peserta didik dan masyarakat.

3) Kompetensi sosial merupakan kemampuan Guru sebagai bagian dari Masyarakatuntuk dapatberkomunikasi secara lisan, tulis, dan/atau isyarat secara santun.

4) Kompetensi profesional merupakan kemampuan Guru dalam menguasai pengetahuan bidang ilmu pengetahuan, teknologi, dan/atau seni dan budaya yang dimiliki.

Dari pengertian diatas, kenyataan yang ada di Sekolah Dasar Negeri No 1 Tiyinggading khususnya siswa kelas V yang umumnya bersifat labil yaitu beberapa siswa masih terpengaruh oleh keadaan sekitar baik bersifat positif dan negative. Namun karena keteladanannya guru mampu memberikan contoh yang baik terhadap siswa untuk bisa bersikap positif. Terbukti dengan keteladanan seorang guru agama Hindu dapat merealisasikan oleh anak-anak Sekolah Dasar No 1 Tiyinggading, contohnya apabila masuk ke kelas setelah siswa mengucapkan salam, siswa menjadi lebih baik dalam mengikuti pelajaran,dan saat pulang kelas siswa mohon restu kepada guru di kelas.

\subsection{Penutup}

Berdasarkan uraian di atas, maka dapat ditarik kesimpulan mengenai Pemanfaatan Media Gambar Hindu Dalam Meningkatkan Minat Belajar Siswa Kelas V Di SD N 1 Tiyinggading adalah sebagai berikut:

1. Kreativitas dilakukan dalam meningkatkan minat belajar siswa kelas $\mathrm{V}$ yaitu, dengan memanfaatkan media gambar Hindu menjadi lebih efektif karena dengan media gambar dapat mempercepat pemahaman siswa kelas V di SD N 1 Tiyinggading.

2. Kendala dalam belajar menggunakan media gambar yaitu proses penyiapan 
materi yang dilakukan oleh guru menjadi lebih lama, kreatifitas seorang guru yang menentukan bagus tidaknya media gambar yang akan di gunakan yang dapat mempengaruhi pemahaman siswa terhadap materi pelajaran, diperlukannya alat bantu dalam menampilkan media gambar yang akan di pergunakan.

3. Manfaat dari media gambar hindu siswa dapat memahami dan membayangkan magsud dari setiap materi agama Hindu yang ada, karena gambar yang dijadikan media dalam pelajaran dapat membuat siswa memahami langkah-langkah yang diperlkukan dalam mempelajari materi agama Hindu.

\section{DAFTAR PUSTAKA}

Asyhar, Rayandra. (2011). Kreatif Mengembangkan

Pembelajaran.

Jakarta : GP Press.

Ahmad Rohani. (1997). Media Instruksional Edukatif. Jakarta: Rineka Cipta

Arikunto, Suharsimi. 2008. Penelitian Tindakan Kelas . Jakarta: Bumi Aksara

Arief S. Sadiman, dkk. (2006). Media Pendidikan, Pengertian, Pengembangan, dan Pemanfaatannya. Jakarta: Pustekkom. Dikbud. dan PT. Raja Grafindo Persada

Badudu, J.S dkk. 2001. Kamus Umum Bahasa Indonesia.

Jakarta:Pustaka Sinar Harapan

Brannen, Julia, 2005, Memadu Metode Penelitian - Kualitatif \& Kuantitatif, Yogyakarta : Pustaka Pelajar.
Depdikbud. (1994). Kurikulum Pendidikan Dasar Garis-Garis Besar Program Pengajaran Kelas $V$ $S D$. Jakarta :Depdikbud.

Moeleong, Lexy J., 2000, Metodologi Penenlitian Kualitatif, Bandung: P.T. Remaja Rosdakarya.

Mulyani Sumantri dan Johar Permata. ( 1998). Strategi Belajar Mengajar. Jakarta: Departemen Pendidikan dan Kebudayaan.

Mulyasa. (2005). Menjadi Guru Profesional. Bandung: PT Remaja Rosdakarya.

Mulyana, Deddy, 2003, Metodologi Penelitian Kualitatif - Paradigma Baru Ilmu Komunikasi dan Ilmu Sosial Lainnya, Bandung : PT. Remaja Rosdakarya.

Miles Huberman. 1997. Analisis Data Kualitatif: buku tentang sumber metode-metode baru. Jakarta. UI-Press.

Nasution, S, 2000, Penelitian Ilmiah, Jakarta : Penerbit Bumi Aksara.

Oemar Hamalik. (2007). Kurikulum dan Pembelajaran. Jakarta: PT Bumi Alsara.

Rita Eka, dkk. (2008). Perkembangan Peserta Didik. Yogyakarta: UNY Press.

Riduawan, Belajar Mudah Penelitian untuk Guru-Karyawan dan Feneliti Pemula.

Bandung: Alfabeta.

Sardiman, A.M. 1992. Interaksi dan Motivasi Belajar Mengajar. PT Rajagrafindo

Sanjaya, Wina. 2006. Stategi Pembelajaran. Jakarta : Upada Sastra

Suharsimi Arikunto. (2002). Prosedur Penelitian. Jakarta: Rineka Cipta

Sukardi.(2003). Metodologi Penelitian Pendidikan. Yogyakarta. PT Bumi Aksara. 
Sugihartono, dkk. (2007). Ilmu Pendidikan. Yogyakarta: UNY Press.

Sugiono, 2011. Metode Penelitian Pendekatan Kuantitatif, Kualitatif, dan R\& D. Bandung : ALFABETA

Salkind Neil J 2009. Teori-Teori

Perkembangan Manusia.

Bandung Nusamedia

Tim Penyusun, 2009. Pedoman Penulisan

Skripsi. Denpasar : UNHI

Tim Penyusun Kamus Pembinaan dan

Pengembangan Bahasa. (2005).

Kamus Besar Bahasa Indonesia.

Jakarta: Balai Pustaka

http:/www.bukucatatan.net/2016/02/cara- paling-berkualitas-

meningkatkan.html\# diakses pada tanggal 2 November 2017 12:00.

Heri,Dewi.(2007). BelajardanPembelajaran Sekolah Dasar. Bandung: UPI Press.

http ://carapedia.com/pengertian_definisi metode_menurut par ahli_ info497.html [4 juni 2012]

Sudjana, Rivai. (2005). Media Pengajaran. Bandung: Sinar BaruAlgensindo.

Zaenal Arifin, M.Pd. 2009. Evaluasi Pembelajaran. Bandung : PT Remaja Rosdakarya. 